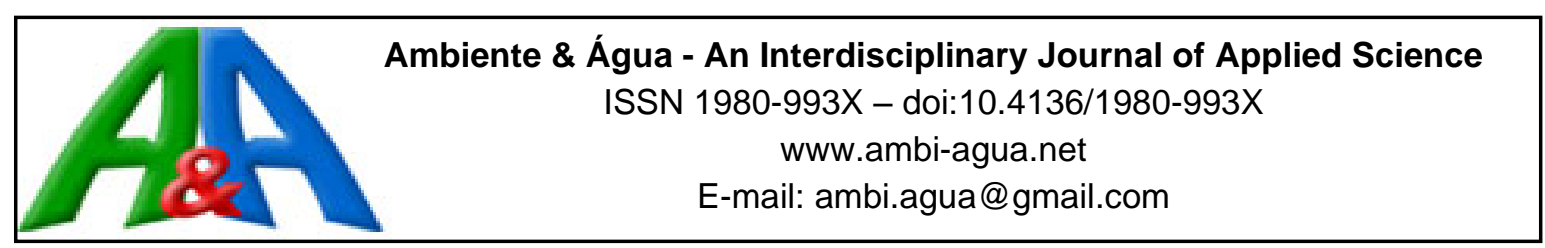

\title{
Treatment of swine wastewater using the Fenton process with ultrasound and recycled iron
}

\author{
ARTICLES doi:10.4136/ambi-agua.2453
}

Received: 19 Aug. 2019; Accepted: 30 Mar. 2020

\author{
Jair Juarez João*(iD; Cíntia Souza da Silva ${ }^{(D)}$ \\ José Luiz Vieira ${ }^{(1)}$ Milena Felipe da Silveira
}

Departamento de Engenharia Química. Centro Tecnológico. Universidade do Sul de Santa Catarina (Unisul), Avenida José Acácio Moreira, n 787, CEP: 88704-900, Tubarão, SC, Brazil. E-mail: cintiass@ hotmail.com, jlvieira1994@uol.com.br, mih_silveira@hotmail.com *Corresponding author. E-mail: jair.joao@unisul.br

\begin{abstract}
Pork production involves the generation of wastewater containing a high pollutant load. Although the biological systems show satisfactory efficiency for the treatment of these effluents, they demand an elevated area for installation and high production of biological sludge. Alternatively, oxidative processes are an alternative for treating such effluents, requiring minor areas and increasing the efficiency of the treatment. We studied the Fenton process assisted with ultrasound for the treatment of swine slaughterhouse wastewater. Nails used in civil construction were used as the iron source. We evaluated the influence of $\mathrm{pH}$, contact time, nail mass, and hydrogen peroxide concentration on color removal, turbidity, chemical oxygen demand (COD) and biochemical oxygen demand (BOD 5 ). The removal of nutrients and oils and greases was also evaluated. The best results using the ultrasound-assisted Fenton process were obtained at $\mathrm{pH} 3$, hydrogen peroxide concentration $90 \mathrm{mg} \mathrm{L}^{-1}$, and a nail unit $(2.7 \mathrm{~g})$. In these conditions, color, turbidity, COD, and BOD 5 removal of 98, 98.2, 84.6, and $98 \%$, respectively, were achieved. The reduction in the other parameters evaluated was above $70 \%$. Catalytic activity maintained above $90 \%$ until the sixth cycle of use. In general, the ultrasound-assisted Fenton process using the nail as a catalyst would be an alternative for the treatment of swine slaughterhouse wastewater. This alternative is responsible for the higher removal of organic load and nutrients in a shorter time when compared with biological systems.
\end{abstract}

Keywords: contaminants, Fenton, organic matter, swine wastewater, ultrasound.

\section{Tratamento de efluentes da suinocultura suínos utilizando o processo Fenton com ultrassom e ferro reciclado}

\section{RESUMO}

A produção de suínos envolve a produção de efluentes líquidos com elevada carga de poluentes. Embora os sistemas biológicos apresnetem eficiência satisfatória para o tratamento destes efluentes eles demandam elevada área para instalação e elevada produção de lodo biológico. Neste sentido, processos oxidativos vêm se apresnetando como uma alternativa para o tratamento de efluentes desta natureza, requerendo menor área e aumentando a eficiência do tratamento. No presente estudo, foi utilizado o processo Fenton assistido com ultrassom no 
tratamento de efluentes de frigorífico de suínos. Como fonte de ferro, foi empregado prego usado em construção civil. Foi estudado a influência do $\mathrm{pH}$, tempo de contato, massa de prego e concentração de peróxido de hidrogênio na remoção de cor, turbidez, demanda química de oxigênio (DQO) e demanda bioquímica de oxigênio $\left(\mathrm{DBO}_{5}\right)$. Foram ainda avaliadas as remoções de nutrientes e óleos e graxas. Os melhores resultados utilizando o processo Fenton assistido por ultrasson foram obtidos em $\mathrm{pH} 3$, concentração de peróxido de hidrogênio $90 \mathrm{mg}$ $\mathrm{L}^{-1}$ e uma unidade de prego $(2,7 \mathrm{~g})$. Nestas condições foram alcançadas remoção de cor, turbidez, DQO e $\mathrm{DBO}_{5}$ de 98, 98,2, 84,6 e 98\%, respectivamente. A redução nos demais parâmetros avaliados foi acima de $70 \%$. Foi ainda avaliada a reutilização do prego, sendo que a atividade catalítica foi mantida acima de $90 \%$ até o sexto ciclo de utilização. De forma geral, o processo Fenton assitido por ultrasson e utilizando prego como catalisador apresenta-se como uma alternativa para o tratamento de efluentes de suinocultura. Esta proposta e de tratamento é responsável por elevada remoção de carga orgânica e nutrientes em um tempo inferior ao observado para sistemas biológicos.

Palavras-chave: contaminantes, efluente de suinocultura, Fenton, matéria orgânica, ultrassom.

\section{INTRODUCTION}

Agribusiness has been developing rapidly in the Brazilian market and is responsible for $20 \%$ of the Gross Domestic Product (GDP). Pig farming, in particular, has become more prominent, making the pork meat industry competitive in the international market (Silva et al., 2018). Currently, Brazil is the fourth-largest producer and exporter of pork in the world, and a growth is observed in this activity (Sebrae, 2019). It is important to emphasize that pig production growth increases the generation of waste and water consumption. This potentially contaminating activity is responsible for several environmental problems related to solid and liquid wastes generated in large volumes (Schlegel et al., 2017; Luo et al., 2018). This wastewater is highly contaminated with suspended solids, dissolved organic matter, nitrogen, viruses, and fecal coliforms. Therefore, it must be treated appropriately to be disposed of without harming the environment (Fongaro et al., 2016; Li et al., 2018; Jaafari et al., 2019).

In this context, the biological treatment (anaerobic and aerobic) are convenient alternatives due to the biodegradability of the compounds present in the aqueous matrix (Waki et al., 2018). Mainly, anaerobic digestion is an alternative that produces biogas and digested substrate, which is a potent fertilizer for organic agriculture (Gopalan et al., 2013). The main advantage of this process is the dispensing of energy (Jaafari et al., 2014). However, as the main drawback, a single system is not able to produce effluents that reach the required environmental standards, requiring additional steps for the treatment (Chen et al., 2015; Wang et al., 2019).

Different coadjuvants (support) for the treatment of liquid effluents generated in swine farming are described in the literature. A promising alternative that could be associated with biological treatment is advanced oxidative processes (AOP). It is responsible for the transformation of organic molecules into carbon dioxide and water, which have attracted the interest of the scientific community (Kanakaraju et al., 2018). AOPs are chemical oxidation techniques based on hydroxyl radical formation $(\mathrm{OH} \bullet)$, a high oxidant able to degrade organic matter in liquid effluents (Vilardi et al., 2018; Brito et al., 2019). In these processes, the hydroxyl radicals act in a non-selective way and allow the degradation of numerous toxic organic contaminants. They are typically transformed into simple molecules, which are readily biodegradable. Alternatively, the total mineralization of all the organic matter present in the effluent is achieved in a short period (Colades et al., 2018; Miklos et al., 2018).

The common AOPs are the Fenton $\left(\mathrm{H}_{2} \mathrm{O}_{2}\right.$ and $\mathrm{Fe}^{+2}$ ions) and photo-Fenton process, when using ultraviolet $(\mathrm{UV})$ source, ozone $\left(\mathrm{O}_{3}\right)$, hydrogen peroxide $\left(\mathrm{H}_{2} \mathrm{O}_{2}\right)$ with $\mathrm{UV}$, titanium dioxide 
$\left(\mathrm{TiO}_{2}\right)$ with UV or different combinations of the cited processes (Huang et al., 2015; Hassanshahi and Karimi-Jashni, 2018; Jiménez et al., 2019). The Fenton process is mostly applied for the removal of organic compounds from liquid effluents (Pera-Titus et al., 2004). Several studies have been developed to improve the performance of the Fenton process by association with electrical energy, light, magnetism, nanoparticle application, electrocoagulation, ultrasound, the use of rotating fixed bed reactors and some alternative materials to replace $\mathrm{Fe}^{+2}$ ions (Babuponnusamy and Muthukumar, 2014; Azerrad et al., 2019). Another production process for hydroxyl radical formation is the use of ultrasound. The ultrasound effect on molecules is related to cavitation, nucleation, growth, and implosion of microbubbles that trap steam/gas. These microbubbles produce areas of high pressure, which lead to water dissociation and formation of $\mathrm{OH} \bullet$, which are responsible for the degradation. The ultrasound irradiation induces electrons' movement number and increasing the $\mathrm{HO}$ • concentration in the medium. Moreover, radial ultrasound may disperse the aggregated catalyst particles, increasing the active surface area (Dobaradaran et al., 2018).

Although the Fenton process is well-described in the literature, most papers reported the use of synthetic wastewater. Nevertheless, industrial effluents are constituted of complex matrices, which may contribute to a decrease in process efficiency (Wang et al., 2016). Additionally, to the best of our knowledge, there are no studies reporting the application of recycled nails as iron sources for the conventional or ultrasound-assisted Fenton. Consequently, we aimed to study the treatment of pork slaughterhouse wastewater using the Fenton process with ultrasound and recycled nails.

\section{MATERIALS AND METHODS}

\subsection{Materials}

The samples of wastewater were obtained from a pork slaughterhouse in southern Brazil. The sampling was carried out according to official Brazilian methodologies NBR 9897 and NBR 9898 (ABNT, 1987a; 1987b). The nails were collected directly on-site (building) and selected according to the more significant number of applications considering the various types of fixation. We used galvanized common nails with a wide head and a smooth shank, size 16/21 $(2.27 \times 47.67 \mathrm{~mm})$. The reactants were all of the analytical purity, hydrogen peroxide $\left(\mathrm{H}_{2} \mathrm{O}_{2}\right.$, $30 \%$, Merck), sulfuric acid $\left(\mathrm{H}_{2} \mathrm{SO}_{4}\right.$, Merck), and sodium hydroxide ( $\mathrm{NaOH}$, Merck).

\subsection{General procedure for Fenton reactions}

The classical Fenton process was conducted under the batch-mode condition using $200 \mathrm{~mL}$ of effluent. The reactions were carried out under different conditions of hydrogen peroxide concentration (30 to $\left.150 \mathrm{mg} \mathrm{L}^{-1}\right)$ and $\mathrm{pH}$ (2 to 6$)$. The mass of the recycled nail $(2.7 \mathrm{~g})$ was fixed. It is equivalent to one nail. The reactor was covered to minimize the effect of photochemical reactions. The temperature of the solution was kept constant at $25^{\circ} \mathrm{C}$ by using a Dubnoff type thermostatic bath, provided by shaking at $20 \mathrm{rpm}$. The hydrogen peroxide was slowly added to minimize the formation of the hydroperoxide radical. A few drops of a $1.0 \mathrm{~mol}$ $\mathrm{L}^{-1} \mathrm{NaOH}$ solution were added to stop the reaction, increasing the $\mathrm{pH}$ to approximately 12 , and consequently precipitating Fe (III). The samples were then filtered to remove the precipitate.

The tests using the ultrasound-assisted methodology were performed in an ultrasound bath (NOVA INSTRUMENTS), under the same conditions aforementioned. The Fenton and ultrasound-assisted Fenton performance was initially assessed by measuring color and turbidity, using a PHARO spectrophotometer (Merck®, Germany). Consequently, the optimal condition was analyzed in terms of $\mathrm{pH}$, color, turbidity, total solids, suspended, dissolved and sedimentable, phosphorus, nitrogen, chemical oxygen demand (COD), biochemical oxygen demand measured in five days (BOD5), and oils and greases. The analyses were performed according to the procedures of the Standard Methods for Examination of Water and Wastewater 
(APHA et al., 2012), and the specific methods are reported in Table 1. The BOD 5 were measured in an Oxitop (WTW ${ }^{\circledR}$, Alemanha), incubated at $20^{\circ} \mathrm{C}$ for five days. The $\mathrm{pH}$ was measured using a HANNA portable $\mathrm{pH}$ meter. All determinations were performed in triplicate.

\subsection{Kinetics of color and turbidity removal}

The kinetic evaluation for color removal and turbidity was performed in an Erlenmeyer flask using $200 \mathrm{~mL}$ of the crude effluent, hydrogen peroxide $\left(90 \mathrm{mg} \mathrm{L}^{-1}\right)$, and one recycled nail $(2.7 \mathrm{~g})$. The $\mathrm{pH}$ was adjusted to 3.0 using sulfuric acid, and the reaction took place in an ultrasonic bath. Aliquots were removed at 10-minute intervals for 60 minutes. The color and turbidity of the samples were analyzed after precipitation of iron at $\mathrm{pH} 12$ and filtering of samples. The pseudo-first-order model was used to fit the experimental data according to Equation 1 (Azizi et al., 2017):

$$
\ln \left(\frac{C}{C_{0}}\right)=-k \cdot t
$$

Where $C$ is the value of color $(\mathrm{Hz})$ or turbidity (NTU) at time $t, C_{0}$ is the initial color or turbidity, and $k$ is the pseudo-first-order rate constant $\left(\mathrm{min}^{-1}\right)$.

\section{RESULTS AND DISCUSSION}

The raw effluent was sampled in a pig slaughterhouse and characterized by physicochemical analyses (Table 1). All the parameters showed high values, demonstrating that this effluent contains a significant load of pollutants. This sample of wastewater was used to carry out all the experiments described in this paper.

\subsection{Effect of pH on color removal and turbidity}

$\mathrm{pH}$ is an essential parameter for the evaluation of color, turbidity, and organic matter removal by advanced oxidation processes (POAs), especially the Fenton process (Zhang and Zhou, 2019). The influence of $\mathrm{pH}$ in the color and turbidity removal is shown in Figure 1 . The removal efficiency decreases as the $\mathrm{pH}$ increases. This observation may be related to iron hydroxide precipitation, which causes the reduction of hydroxyl radicals $(\mathrm{OH} \bullet)$ due to the lack of free iron ions, which accelerates the decomposition of hydrogen peroxide in oxygen, reducing its oxidative capacity (Szpyrkowicz et al., 2001). Moreover, the efficiency of color and turbidity removal also decreases at $\mathrm{pH}$ less than 3 as stable or non-reactive species such as oxon ion $\left(\mathrm{H}_{3} \mathrm{O}_{2}{ }^{+}\right)$and iron complexes $\left[\mathrm{Fe}\left(\mathrm{H}_{2} \mathrm{O}\right)_{6}\right]^{+2}$ are formed, (Huang et al., 2017). Also, other reactions may be occurring at lower $\mathrm{pHs}$ during the reaction. In these reactions, the hydroxyl radical $(\mathrm{OH} \bullet)$ generated can oxidize ferrous ions (Equation 2), and react with hydrogen peroxide (Equation 3). In these cases, ferrous ion and hydrogen peroxide are acting as sequestering agents of hydroxyl radicals in the medium, which may decrease process efficiency at low $\mathrm{pH}$.

$$
\begin{aligned}
& \mathrm{Fe}^{+2}+\mathrm{OH}^{\bullet} \rightarrow \mathrm{Fe}^{+3}+\mathrm{OH}^{-} \\
& \mathrm{H}_{2} \mathrm{O}_{2}+\mathrm{OH}^{\bullet} \rightarrow \mathrm{H}_{2} \mathrm{O}+\mathrm{HO}_{2}^{\bullet}
\end{aligned}
$$

The best results were obtained at $\mathrm{pH} 3$, regardless of the hydrogen peroxide concentration used. This result corroborates with other authors who found that the best performance of the Fenton process was achieved in the $\mathrm{pH}$ range of 3 and 4 (Kavitha and Palanivelu, 2004; Lee and Shoda, 2008; Pouran et al., 2015). Besides, at $\mathrm{pH} \mathrm{3,} \mathrm{a} \mathrm{higher} \mathrm{rate} \mathrm{of} \mathrm{nail} \mathrm{oxidation} \mathrm{is}$ observed (residual nail content $15 \mathrm{mg} \mathrm{L}^{-1}$ ), which contributes to the homogeneous Fenton process. In this process, ferrous ion $\left(\mathrm{Fe}^{+2}\right)$ may be contributing to the decomposition of $\mathrm{H}_{2} \mathrm{O}_{2}$, 
resulting in the generation of more hydroxyl radicals, which act by oxidizing organic pollutants, contributing to better efficiency of the process. At $\mathrm{pH} 2,3,4,5$, and 6 , the values obtained for color removal using the Fenton process were $88,96.8,91.5,74$, and $65 \%$, respectively. The turbidity was highly removed when compared to the color of the wastewater. The values obtained for turbidity removal at $\mathrm{pH} 2$ were 88.8\%, pH 3 (99\%), pH 4 (92\%), pH 5 (88\%) and pH $6(87 \%)$ (Figure 1). These results may be related to particulate material present in the raw effluent (turbidity 1560 FAU), which contributes to the coagulation and flocculation process, as a function of $\mathrm{pH}$ elevation ( $\mathrm{pH} 12)$ associated with the iron precipitation. The values of color and turbidity removal were above 95\% using the Fenton process and 98\% for the ultrasoundassisted process. The best results obtained with Fenton processes were obtained at $\mathrm{pH} 3$ and 90 minutes of reaction, regardless of the hydrogen peroxide concentration. It was also observed that better results were obtained with the hydrogen peroxide concentration of $90 \mathrm{mg} \mathrm{L}-1$.
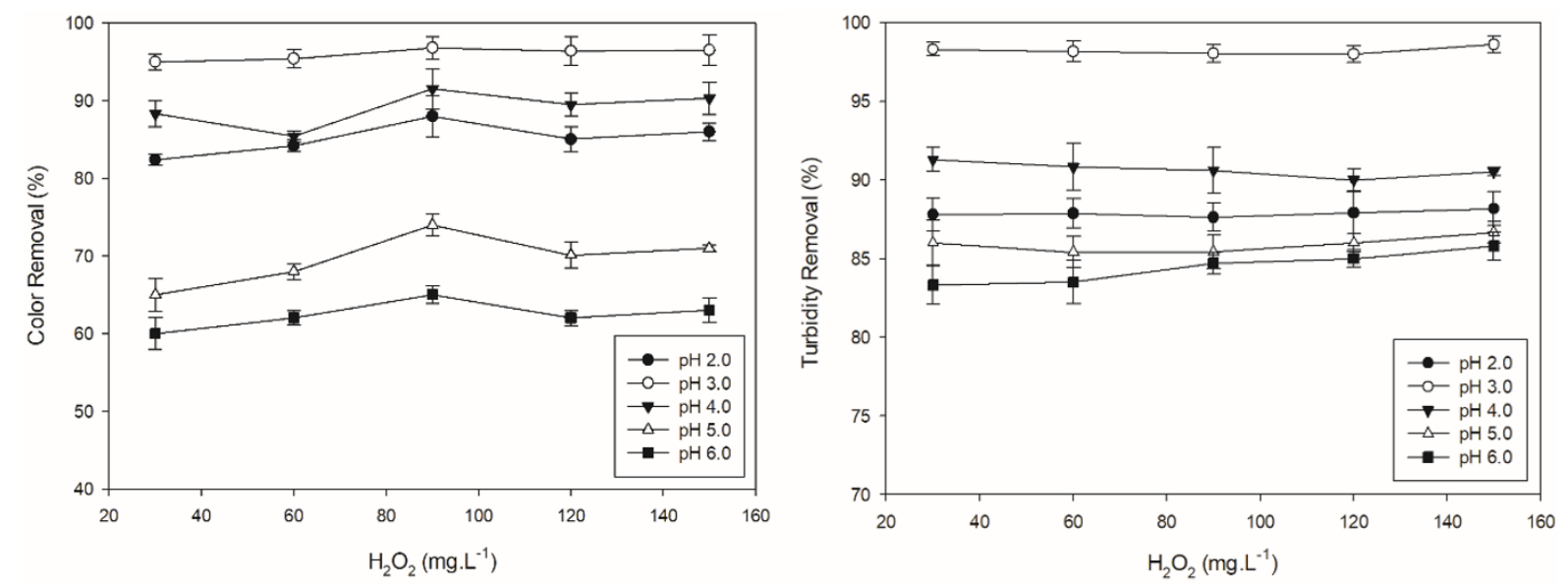

Figure 1. The effect of $\mathrm{pH}$ and hydrogen peroxide removal on color (left) and turbidity (right) using the Fenton process. Time of reaction of 90 minutes.

Similar results were obtained for the ultrasound-assisted Fenton process in 60 minutes of reaction. In this case, the removal was $97 \%$ for color and $99.5 \%$ for turbidity. This result means that the ultrasound reduces the time required to obtain the same results by 30 minutes when compared to the traditional Fenton process. After obtaining the optimal condition of $\mathrm{pH}$, time, and concentration of hydrogen peroxide, kinetic experiments were carried out to evaluate color removal and turbidity over time. The data are shown in Figure 2.
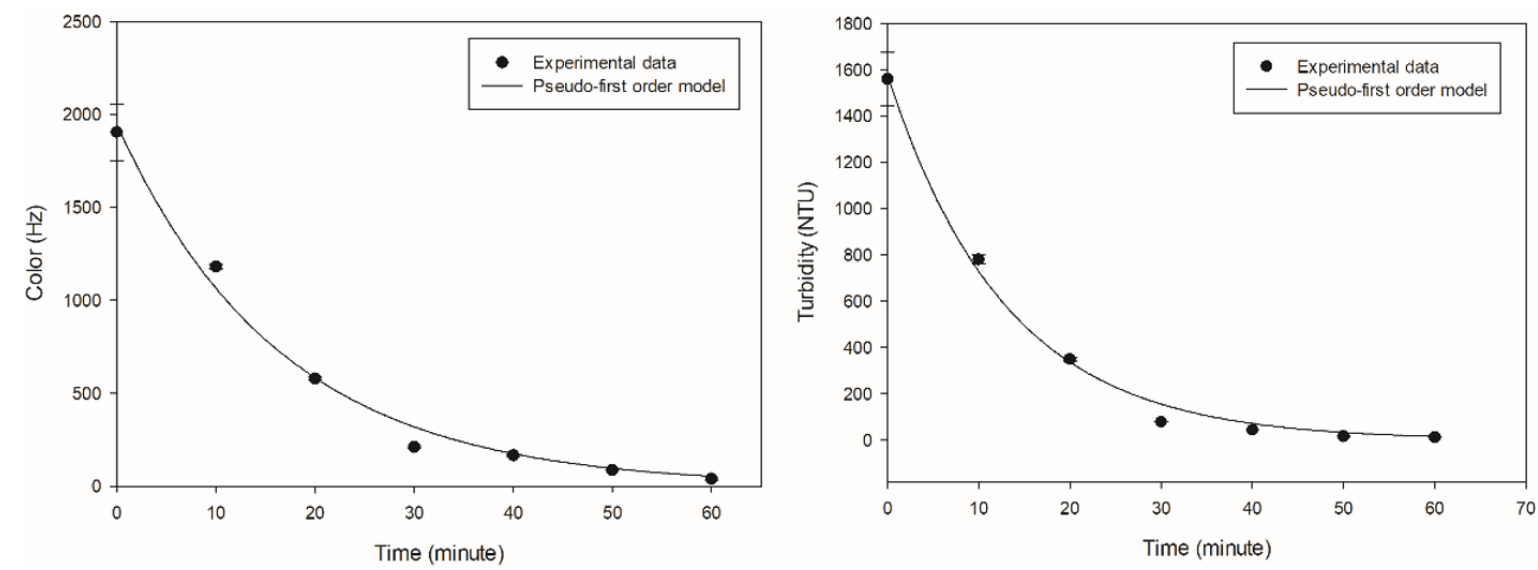

Figure 2. Kinetic evaluation for color and turbidity removal using the Fenton process with ultrasound at $\mathrm{pH} 3$ and hydrogen peroxide concentration of $90 \mathrm{mg} \mathrm{L}^{-1}$. 
The pseudo-first-order model fit well to the experimental data, and the $\mathrm{R}^{2}$ was 0.9905 and 0.9950 for color and turbidity, respectively. The pseudo-first-order rate constants were 0.0604 and $0.0773 \mathrm{~min}^{-1}$, for color and turbidity, respectively. It can be observed that color (89\%) and turbidity removal $(95 \%)$ is obtained in 30 minutes. This fact is due to the higher consumption of hydrogen peroxide and the superficial mass of iron of the nail at the beginning of the reaction. Small changes occurred due to the variation of the organic contaminants in the different raw effluent samples between 30 and 40 minutes. After this step, the ultrasonic-assisted Fenton reaction continued, and the reaction equilibrium was reached at 50 minutes. At this moment, the effluent was clarified entirely, achieving $95.5 \%$ and $98.9 \%$ for color and turbidity removal, respectively (Figure 2). However, similar removal percentages were obtained using the traditional Fenton process in 90 minutes. We obtained removals of $96.8 \%$ for color and $99 \%$ for turbidity. Thus, the Fenton process assisted with ultrasound proved to be an efficient alternative, reducing the treatment time. These data corroborate other studies in the literature that reported that the Fenton process with ultrasound and or aeration might decrease the treatment time (Cetinkaya et al., 2018).

The removal of the organic matter present in the effluent was also evaluated. The presence of this type of contaminant is a critical parameter to measure effluent quality. The efficiency of the Fenton process with ultrasound for organic matter removal was evaluated through the COD, and $\mathrm{BOD}_{5}$ analyzes, considering different $\mathrm{pH}$ conditions and hydrogen peroxide concentration of $90 \mathrm{mg} \mathrm{L}^{-1}$ and 60 minutes. All determinations were performed in triplicate, and the average removal results are shown in Figure 3. In general, the values obtained for COD removal varied according to the $\mathrm{pH}$. The highest removal was observed at $\mathrm{pH} 3$ (84.6\%). At $\mathrm{pH} 2,4,5$, and 6, the removals were $68.4,63,55.8$, and $50.5 \%$, respectively. Similar results were observed for $\mathrm{BOD}_{5}$. The mean removal of $\mathrm{BOD}_{5}$ was $98 \%$ at $\mathrm{pH} 3$. Increasing the $\mathrm{pH}$, the values for $\mathrm{BOD}_{5}$ removal decreased to $91 \%$ at $\mathrm{pH} 4,72 \%$ at $\mathrm{pH} 5$, and $63 \%$ at $\mathrm{pH} 6$.
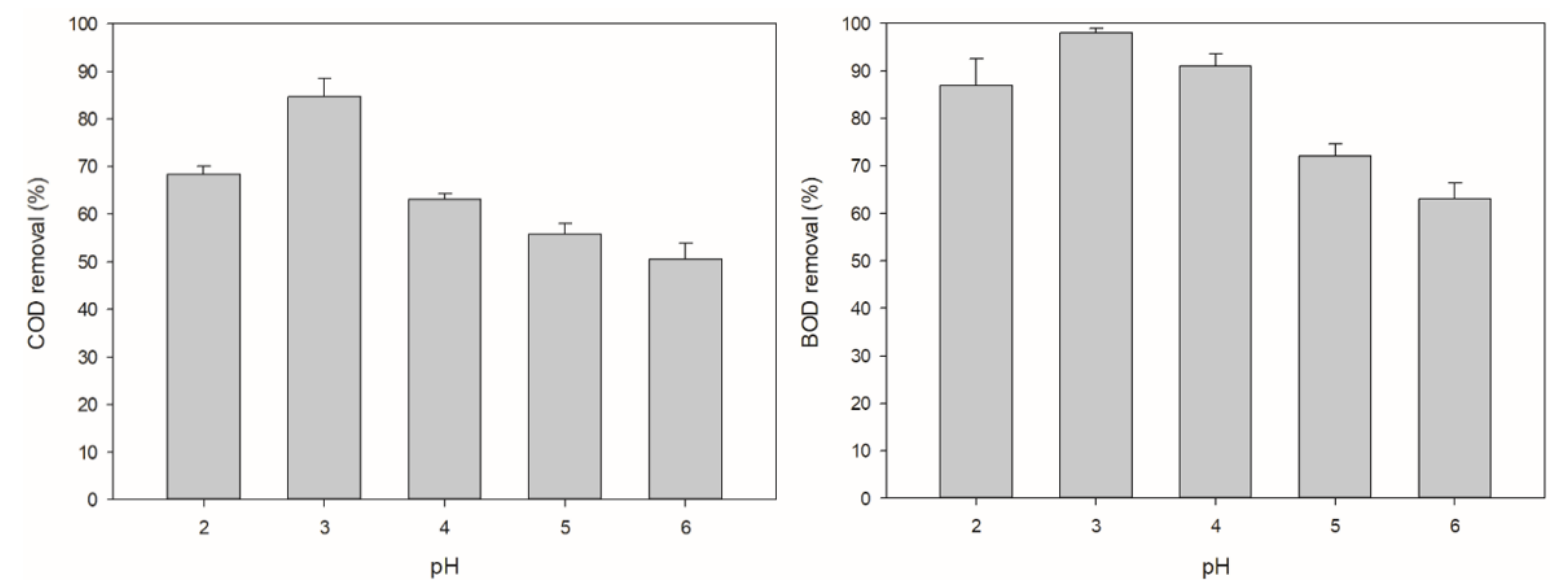

Figure 3. Removal of COD (left) and $\mathrm{BOD}_{5}$ (right) at different pHs and concentrations of hydrogen peroxide of $90 \mathrm{mg} \mathrm{L}^{-1}$.

These results allowed us to define the optimal condition for the reaction $(\mathrm{pH} 3$, time of 60 minutes, $90 \mathrm{mg} \mathrm{L}^{-1}$ of $\mathrm{H}_{2} \mathrm{O}_{2}$, and one nail). Following this, many analyses were carried out for the effluent treated using the ultrasound-assisted Fenton process and compared to the raw one. These analyses are shown in Table 1.

The results demonstrated significant reductions for all parameters analyzed. It also confirms that Fenton ultrasound-assisted treatment is efficient for such wastewater. In general, the average efficiency was above $95 \%$, and the best results were observed in the removal of color $(98 \%)$, turbidity $(98.2 \%)$, and $\mathrm{BOD}_{5}(98 \%)$. However, the values for COD, phosphorus, and oils and fats were below $90 \%$. These values may be associated with the total dissolved 
solids present in the treated effluent, which leads to the formation of the residual organic matter iron complex, inorganic ions, and some water-soluble organic by-products formed during the chemical degradation process (Queiroz et al., 2011). Figure 4 presents the raw and treated wastewater with ultrasound-assisted Fenton after filtration.

Table 1. Results obtained for the characterization of the raw and treated effluent using the ultrasound-assisted Fenton at the optimal condition.

\begin{tabular}{|c|c|c|c|c|}
\hline Parameters & Raw & Treated & Removal (\%) & Method \\
\hline Color $(\mathrm{Hz})$ & $1904 \pm 114$ & $38 \pm 5$ & 98 & SM $2120 \mathrm{C}$ \\
\hline Turbidity (NTU) & $1560 \pm 94$ & $29 \pm 3$ & 98,2 & SM $2130 \mathrm{~B}$ \\
\hline $\operatorname{COD}\left(\mathrm{mg} \mathrm{L}^{-1}\right)$ & $4830 \pm 326$ & $743 \pm 55$ & 84,6 & SM $5220 \mathrm{D}$ \\
\hline $\mathrm{BOD}_{5}\left(\mathrm{mg} \mathrm{L}^{-1}\right)$ & $3018 \pm 232$ & $60,3 \pm 20$ & 98 & SM 5210 B \\
\hline Oils and Greases (mg L $\left.{ }^{-1}\right)$ & $100 \pm 5,6$ & $30,1 \pm 4,2$ & 70 & SM $5520 \mathrm{D}$ \\
\hline Suspended Solids (mg L $\mathrm{L}^{-1}$ ) & $385 \pm 56$ & $24 \pm 3,5$ & 93,7 & SM $2540 \mathrm{D}$ \\
\hline Sedimentable Solids $\left(\mathrm{mg} \mathrm{L}^{-1}\right)$ & $30 \pm 6,8$ & ND & 100 & SM 2540F \\
\hline Total Solids (mg L $\left.{ }^{-1}\right)$ & $1000 \pm 94$ & $58,5 \pm 5,5$ & 94,2 & SM 2540B \\
\hline Total dissolved solids $\left(\mathrm{mg} \mathrm{L}^{-1}\right)$ & $530 \pm 46$ & $29,8 \pm 3,2$ & 94,4 & SM $2540 \mathrm{C}$ \\
\hline Phosphorus (mg L ${ }^{-1}$ ) & $18,4 \pm 3,2$ & $2,06 \pm 0,3$ & 88,8 & SM 4500-P E \\
\hline Total Nitrogen (mg L $\left.{ }^{-1}\right)$ & $152 \pm 24$ & $6,6 \pm 1,5$ & 95,6 & EPA 1687 \\
\hline
\end{tabular}

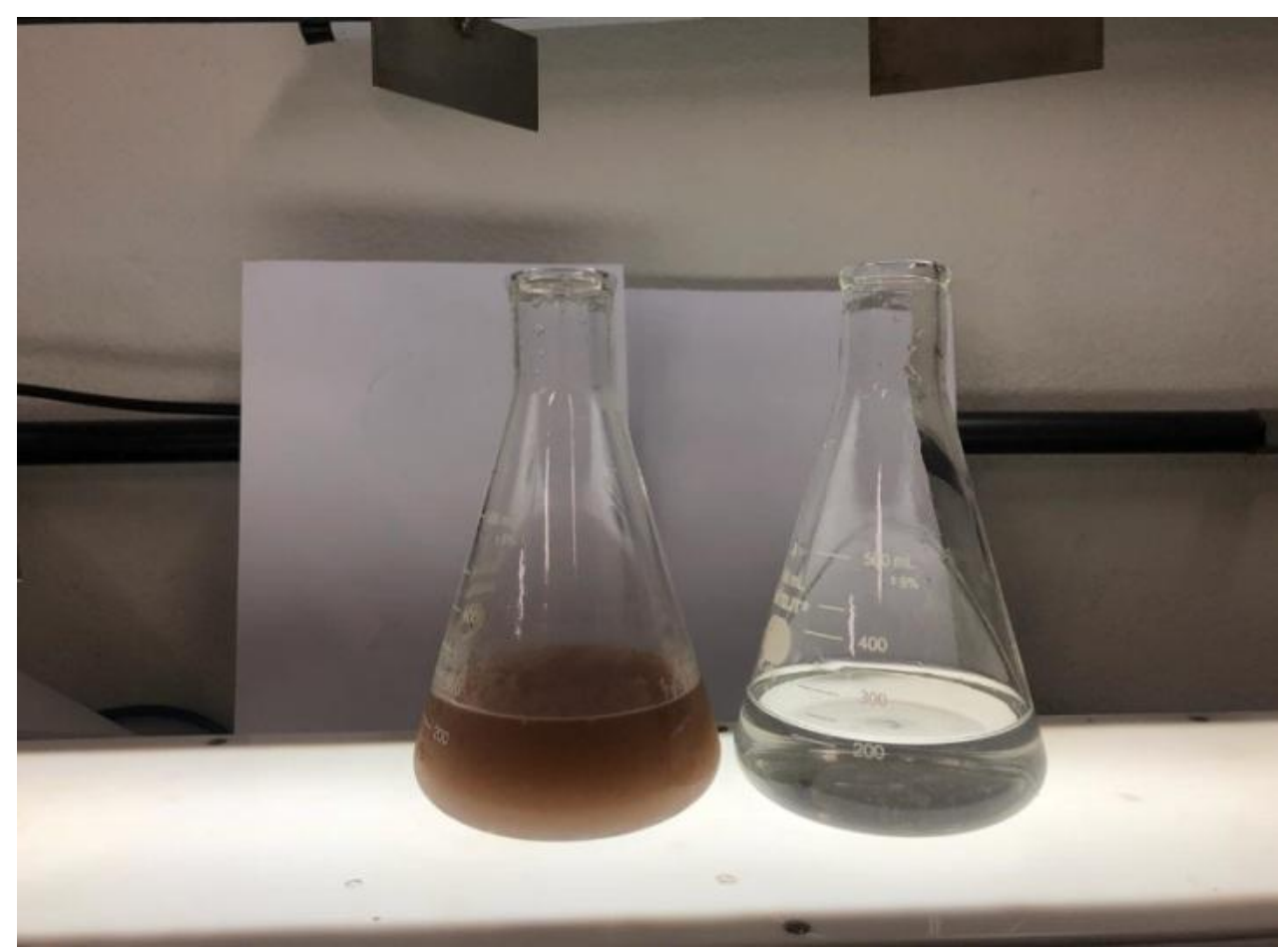

Figure 4. Raw (left) and treated (right) effluent after filtration. 
Additionally, the nail reuse capacity was studied. The results showed the possibility of reuse of the nail in 6 treatment cycles for color removal. The sixth cycle retained over $90 \%$ of the initial catalytic capacity (Figure 5).

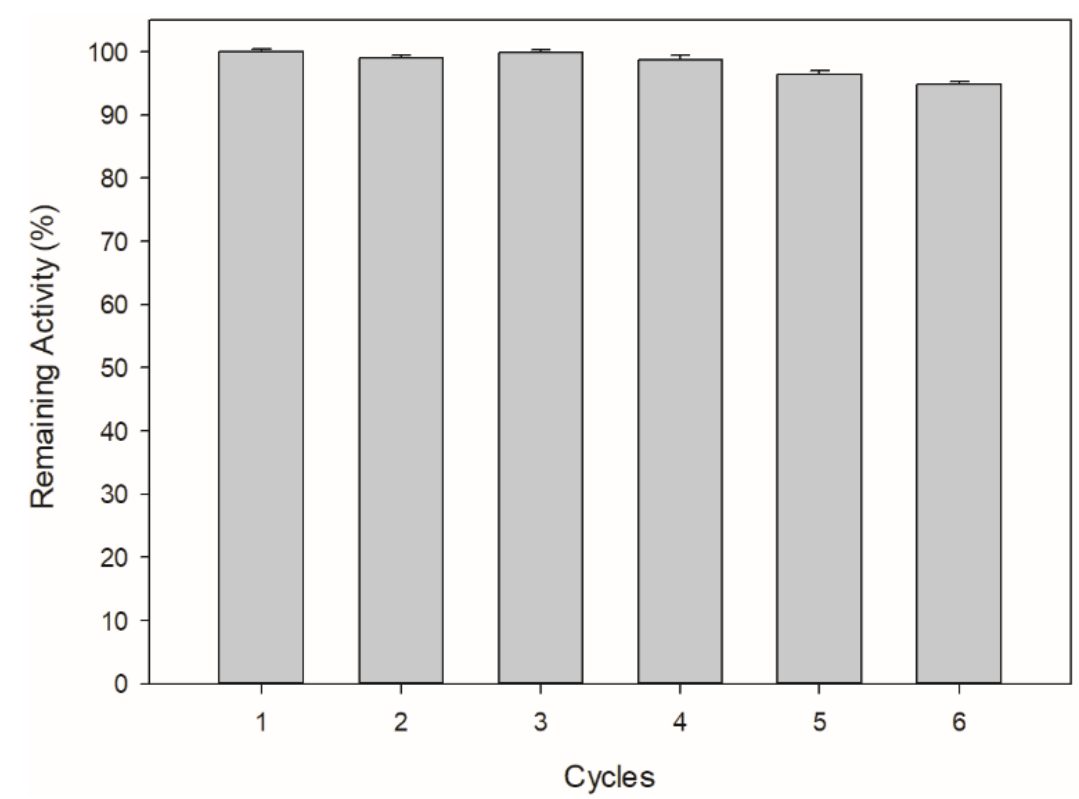

Figure 5. Remaining catalytic activity of nails after many reuse cycles in terms of color removal.

Overall, in the literature, several methods, such as electrolysis, precipitation, coagulation, and ion exchange, are applied for the removal of organic contaminants from liquid effluents (Casado et al., 2019; Güneş et al., 2019). However, many of these methods generate new problems, such as more waste and, in some cases, more hazardous waste (Güneş et al., 2019). The Fenton process is one of the most effective for removing organic matter from liquid effluents, as hydroxyl radicals act in a non-selective manner, which enables the total degradation of organic contaminants, thus generating a smaller volume of solid waste. (Babuponnusamy and Muthukumar, 2014). Further, the Fenton process promotes the destruction of the contaminant in the aqueous phase and not only the phase transfer of pollutants, as occurs in the adsorption, coagulation, and flocculation processes. Desirable products for the Fenton process are carbon dioxide, water, inorganic ions, and less toxic byproducts (Queiroz et al., 2011).

\section{CONCLUSION}

This study showed that the use of the ultrasonic-assisted Fenton process was an efficient alternative for the removal of organic contaminants present in the effluents from a pork slaughterhouse. The method was able to remove both suspended and dissolved constituents. Nutrients such as phosphorus and nitrogen were also removed. We also demonstrated that recycled nails could be used as an iron source for Fenton, and this material can be used in many reaction cycles. Further studies should be done to evaluate the toxicological effects of this treatment, and also to assess the removal of contaminants of emerging concern.

\section{REFERENCES}

APHA; AWWA; WEF. Standard Methods for the examination of water and wastewater. $22^{\text {nd }}$ ed. Washington, 2012. 
ABNT. NBR 9897: Planejamento de amostragem de efluentes líquidos e corpos receptores. Rio de Janeiro, 1987a.

ABNT. NBR 9898: Preservação e técnicas de amostragem de efluentes líquidos e corpos receptores. Rio de Janeiro, $1987 \mathrm{~b}$.

AZERRAD, S. P.; ISAACS, M.; DOSORETZ, C. G. Integrated treatment of reverse osmosis brines coupling electrocoagulation with advanced oxidation processes. Chemical Engineering Journal, v. 356, p. 771-780, 2019. http://doi:10.1016/j.cej.2018.09.068

AZIZI, E.; FAZLZADEH, M.; GHAYEBZADEH, M.; HEMATI, L.; BEIKMOHAMMADI, M.; GHAFFARI, H. R.; ZAKERI, H. R.; SHARAFI, K. Application of advanced oxidation process $\left(\mathrm{H}_{2} \mathrm{O}_{2} / \mathrm{UV}\right)$ for removal of organic materials from pharmaceutical industry effluent. Environment Protection Engineering, v. 43, p. 183-191, 2017. http://doi:10.5277/epe170115

BABUPONNUSAMY, A.; MUTHUKUMAR, K. A review on Fenton and improvements to the Fenton process for wastewater treatment. Journal of Environmental Chemical Engineering, v. 2, n. 1, p. 557-572, 2014. http://doi:10.1016/j.jece.2013.10.011

BRITO, G. F. S.; OLIVEIRA, R.; GRISOLIA, C. K.; GUIRRA, L. S.; WEBER, I. T.; ALMEIDA, F. V. Evaluation of advanced oxidative processes in biodiesel wastewater treatment. Journal of Photochemistry and Photobiology A: Chemistry, v. 375, p. 8590, 2019. https://doi.org/10.1016/j.jphotochem.2019.01.013

CASADO, J. Towards industrial implementation of electro-fenton and derived technologies for wastewater treatment: a review. Journal of Environmental Chemical Engineering, v.7, p. 1-15, 2019. https://doi.org/10.1016/j.jece.2018.102823

CETINKAYA, S. G.; MORCALI, M. H.; AKARSU, S.; ZIBA, C. A.; DOLAZ, M. Comparison of classic Fenton with ultrasound Fenton processes on industrial textile wastewater. Sustainable Environment Research, v.28, n.4, 165-170, 2018. http://doi:10.1016/j.serj.2018.02.001

CHEN, Q.; YANG, Y.; ZHOU, M.; LIU, M.; YU, S.; GAO, C. Comparative study on the treatment of raw and biologically treated textile effluents through submerged nanofiltration. Journal of Hazardous Materials, v. 284, p. 121-129, 2015. http://dx.doi.org/10.1016/j.jhazmat.2014.11.009

COLADES, J. I.; DE LUNA, M. D. G.; SUMALINOG, D. A. G.; HUANG, C.P. Application of mathematical modeling and electrochemical iron dosing strategies to improve the treatment performance of the electro-Fenton process. Journal of Cleaner Production, v. 181, p. 437-448, 2018. http://doi:10.1016/j.jclepro.2018.01.147

DOBARADARAN, S.; NODEHI, R. N.; YAGHMAEIAN, K.; JAAFARI, J.; NIARI, M. H.; BHARTI, A. K.; SHARIATIFAR, N. Catalytic decomposition of 2-chlorophenol using an ultrasonic-assisted Fe3O4-TiO2@MWCNT system: Influence factors, pathway and mechanism study. Journal of Colloid and Interface Science, v. 512, p. 172-189, 2018. http://doi:10.1016/j.jcis.2017.10.015

FONGARO, G.; KUNZ, A.; MAGRI, M. E.; SCHISSI, C. D.; VIANCELLI, A.; PHILIPPI, L. S.; BARARDI, C. R. M. Settling and survival profile of enteric pathogens in the swine effluent for water reuse purpose. International Journal of Hygiene and Environmental Health, v. 219, p. 883-889, 2016. http://doi:10.1016/j.ijheh.2016.07.004 
GOPALAN, P.; JENSEN, P. D.; BATSTONE, D. J. Anaerobic digestion of swine effluent: Impact of production stages. Biomass and Bioenergy, v. 48, p. 121-129, 2013. http://doi:10.1016/j.biombioe.2012.11.012

GÜNEŞ, E.; DEMIR, E.; GÜNEŞ, Y.; HANEDAR, A. Characterization and treatment alternatives of industrial container and drum cleaning wastewater: Comparison of Fentonlike process and combined coagulation/oxidation processes. Separation and Purification Technology, 209, 426-433, 2019. http://doi:10.1016/j.seppur.2018.07.060

HASSANSHAHI, N.; KARIMI-JASHNI, A. Comparison of photo-Fenton, $\mathrm{O}_{3} / \mathrm{H}_{2} \mathrm{O}_{2} / \mathrm{UV}$ and photocatalytic processes for the treatment of greywater. Ecotoxicology and $\begin{array}{llllll}\text { Environmental Safety, } & \text { v. } & \text { 161, } & \text { p. } & 683-690, & \end{array}$ http://doi:10.1016/j.ecoenv.2018.06.039

HUANG, D.; HU, C.; ZENG, G.; CHENG, M.; XU, P.; GONG, X.; XUE, W. Combination of Fenton processes and biotreatment for wastewater treatment and soil remediation. Science of the Total Environment, v. 574, p. 1599-1610, 2017. http://dx.doi.org/10.1016/j.scitotenv.2016.08.199

HUANG, D. L.; WANG, C.; XU, P.; ZENG, G.M.; LU, B. A.; LI, N. J.; LUO, X.Y. A coupled photocatalytic-biological process for phenol degradation in the Phanerochaete chrysosporium-oxalate-Fe3O4 system. International Biodeterioration \& Biodegradation, v. 97, p. 115-123, 2015. http://doi:10.1016/j.ibiod.2014.11.001

JAAFARIA, J.; JAVIDB, A. B.; BARZANOUNIC, H.; YOUNESID, A.; AMIR, N.; FARAHANIE, A., MOUSAZADEHF, M.; SOLEIMANIE, P. Performance of modified one-stage Phoredox reactor with hydraulic up-flow in biological removal of phosphorus from municipal wastewater. Desalination and Water Treatment, v. 171, p.16-222, 2019. http://doi:10.5004/dwt.2019.24752

JAAFARI, J.; MESDAGHINIA, A.; NABIZADEH, R.; HOSEINI, M.; KAMANI, H.; MAHVI, A. H. Influence of upflow velocity on performance and biofilm characteristics of Anaerobic Fluidized Bed Reactor (AFBR) in treating high-strength wastewater. Journal of Environmental Health Science and Engineering, v. 12, p. 1, 2014. http://doi:10.1186/s40201-014-0139-x

JIMÉNEZ, S.; ANDREOZZI, M.; MICÓ, M. M.; ÁlVAREZ, M. G.; CONTRERAS, S. Produced water treatment by advanced oxidation processes. Science of The Total Environment, v. 666, p. 12-21, 2019. http://doi:10.1016/j.scitotenv.2019.02.128

KANAKARAJU, D.; GLASS, B. D.; OELGEMÖLLER, M. Advanced oxidation processmediated removal of pharmaceuticals from water: A review. Journal of Environmental Management, v. 219, p. 189-207, 2018. http://doi:10.1016/j.jenvman.2018.04.103

KAVITHA, V.; PALANIVELU, K. The role of ferrous ion in Fenton and photo-Fenton processes for the degradation of phenol. Chemosphere, v. 55 p. 1235-1243, 2004. http://dx.doi.org/10.1016/j.chemosphere.2003.12.022

LEE, H.; SHODA, M. Removal of COD and color from livestock wastewater by the Fenton method. Journal of Hazardous Materials, v. 153 p. 1314-1319, 2008. http://dx.doi.org/10.1016/j.jhazmat.2007.09.097

LI, X.; CHEN, S.; ANGELIDAKI, I.; ZHANG, Y. Bio-electro-Fenton processes for wastewater treatment: Advances and prospects. Chemical Engineering Journal, v. 354, p. 492-506, 2018. http://doi:10.1016/j.cej.2018.08.052 
LUO, P.; LIU, F.; ZHANG, S.; LI, H.; CHEN, X.; WU, L.; WU, J. Evaluating organics removal performance from lagoon-pretreated swine wastewater in pilot-scale three-stage surface flow constructed wetlands. Chemosphere, v. 211, p. 286-293, 2018. http://doi:10.1016/j.chemosphere.2018.07.174

MIKLOS, D. B.; REMY, C.; JEKEL, M.; LINDEN, K. G.; DREWES, J. E.; HÜBNER, U. Evaluation of advanced oxidation processes for water and wastewater treatment - A critical review. Water Research, v. 139, p. 118-131, 2018. http://doi:10.1016/j.watres.2018.03.042

PERA-TITUS, M.; GARCÍA-MOLINA, V.; BAÑOS, M. A.; GIMÉNEZ, J.; ESPLUGAS, S. Degradation of chlorophenols by means of advanced oxidation processes: a general review. Applied Catalysis B: Environmental, v. 47, n. 4, p. 219-256, 2004. http://doi:10.1016/j.apcatb.2003.09.010

POURAN, S. R.; AZIZ, A. R. A.; DAUD, W. M. A. W. Review on the main advances in photoFenton oxidation system for recalcitrant wastewaters. Journal of Industrial and $\begin{array}{llllll}\text { Engineering Chemistry, } & \text { v. 21, } & \text { p. }\end{array}$ http://dx.doi.org/10.1016/j.jiec.2014.05.005

QUEIROZ, M. T. A.; FERNANDES, C. M.; ALVIM, L. B.; COSTA, T. C.; AMORIM, C. C. Produção mais limpa: Fenton homogêneo no tratamento de efluentes têxteis. In: Simpósio de excelência em gestão e tecnologia, 8., 2011, Resende. Trabalhos[...] Resende: AEDB, 2011.

SEBRAE. Noções iniciais para investir em suinocultura. Available at: http://www.sebrae.com.br Access: Aug. 2019.

SCHLEGEL, A. J.; ASSEFA, Y.; BOND, H. D.; HAAG, L. A.; STONE, L. R. Changes in soil nutrients after 10 years of cattle manure and swine effluent application. Soil and Tillage Research, v. 172, p. 48-58, 2017. http://doi:10.1016/j.still.2017.05.004

SILVA, F. P.; DE SOUZA, S. N. M.; KITAMURA, D. S.; NOGUEIRA, C. E. C.; OTTO, R. B. Energy efficiency of a micro-generation unit of electricity from biogas of swine manure. Renewable and Sustainable Energy Reviews, v. 82, p. 3900-3906, 2018. http://doi:10.1016/j.rser.2017.10.083

SZPYRKOWICZ, L.; JUZZOLINO, C.; KAUL, S. N. A. Comparative study on oxidation of disperse dyes by electrochemical process, ozone, hypochlorite and fenton reagent. Water Research, v. 35, p. 2129-2136, 2001. https://dx.doi.org/10.1016/s0043-1354(00)00487-5

VILARDI, G.; SEBASTIANI, D.; MILIZIANO, S.; VERDONE, N.; DI PALMA, L. Heterogeneous nZVI-induced Fenton oxidation process to enhance biodegradability of excavation by-products. Chemical Engineering Journal, v. 335, p. 309-320, 2018. http://doi:10.1016/j.cej.2017.10.152

WAKI, M.; YASUDA, T.; FUKUMOTO, Y.; BÉLINE, F.; MAGRÍ, A. Treatment of swine wastewater in continuous activated sludge systems under different dissolved oxygen conditions: Reactor operation and evaluation using modelling. Bioresource Technology, 250, 574-582, 2018. http://doi:10.1016/j.biortech.2017.11.078

WANG, N.; ZHENG, T.; ZHANG, G.; WANG, P. A review on Fenton-like processes for organic wastewater treatment. Journal of Environmental Chemical Engineering, v. 4, n. 1, p. 762-787, 2016. http://doi:10.1016/j.jece.2015.12.016 
WANG, L.; ADDY, M.; LIU, J.; NEKICH, C.; ZHANG, R.; PENG, P.; RUAN, R. Integrated Process for Anaerobically Digested Swine Manure Treatment. Bioresource Technology, v. 273, p. 506-514, 2019. http://doi:10.1016/j.biortech.2018.11.050

ZHANG, Y.; ZHOU, M. A critical review of the application of chelating agents to enable Fenton and Fenton-like reactions at high $\mathrm{pH}$ values. Journal of Hazardous Materials, v. 362, p. 436-450, 2019. http://doi:10.1016/j.jhazmat.2018.09.035 